\title{
Teaching NeuroImages: MRI Abnormalities of Spinal Dural Arteriovenous Fistula in the Absence of Flow Voids
}

Andre Miguel Miranda, MD, PhD, Marta Gomes Rodrigues, MD, Andre Araujo, MD,

Manuel Queiros Ribeiro, MD, Henrique Costa, MD, and Sergio Castro, MD

Neurology ${ }^{\circledR}$ 2021;97:e324-e325. doi:10.1212/WNL.0000000000012053

A 66-year-old woman presented with progressive spastic paraplegia and lumbar pain. Physical examination revealed hyperreflexia in lower extremities, reduced pinprick and vibration up to D12, and impaired hallux proprioception. Spinal MRI revealed multilevel centromedullary T2 hyperintensity and diffuse contrast enhancement except for abrupt intralesional segment (missing piece; figure 1).

Unremarkable blood and CSF workup and persistent imaging findings at 6-month follow-up prompted selective angiography, which confirmed a spinal dural arteriovenous fistula (sDAVF) at L1 (figure 2). Successful endovascular embolization improved imaging and functional status. In the appropriate clinical scenario, absence of flow voids does not exclude sDAVFs. The unique missing piece enhancement pattern may expedite differential diagnosis. ${ }^{1,2}$

Figure $1 \mathrm{MRI}$ Assessment of Progressive Myelopathy

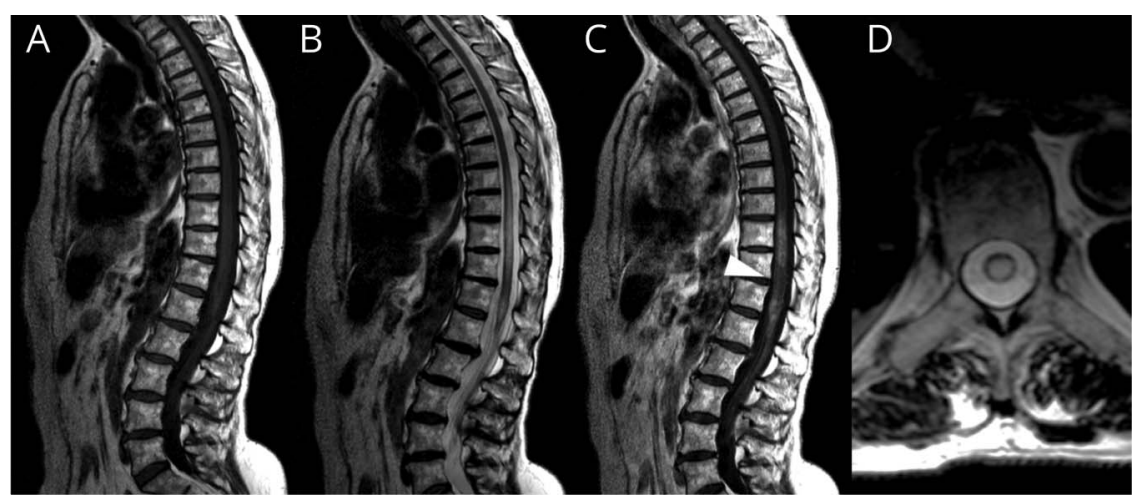

(A) T1-weighted imaging demonstrates isointense conus medullaris. (B) T2-weighted imaging reveals diffuse multilevel hyperintensity from D7-L1 with hypointense signal at D11-D12. No prominent tortuous flow voids are present. (C) Postgadolinium T1-weighted imaging shows diffuse contrast enhancement with abrupt isointense segment (missing piece sign) (arrowhead). (D) Axial T2-weighted imaging shows centromedullary hyperintensity.

\section{Study Funding}

No targeted funding reported.

\section{Disclosure}

The authors report no disclosures relevant to the manuscript. Go to Neurology.org/N for full disclosures.

\section{Correspondence}

Dr. Castro

snacastro@gmail.com

\section{MORE ONLINE}

$\rightarrow$ Teaching slides

links.lww.com/WNL/

B375

From the Department of Imagiology, Neuroradiology Unit (A.M.M., M.G.R., A.A., M.Q.R., S.C.), and Department of Neurology (H.C.), Centro Hospitalar de Vila Nova de Gaia/Espinho EPE, Vila Nova de Gaia, Portugal.

Go to Neurology.org/N for full disclosures. 

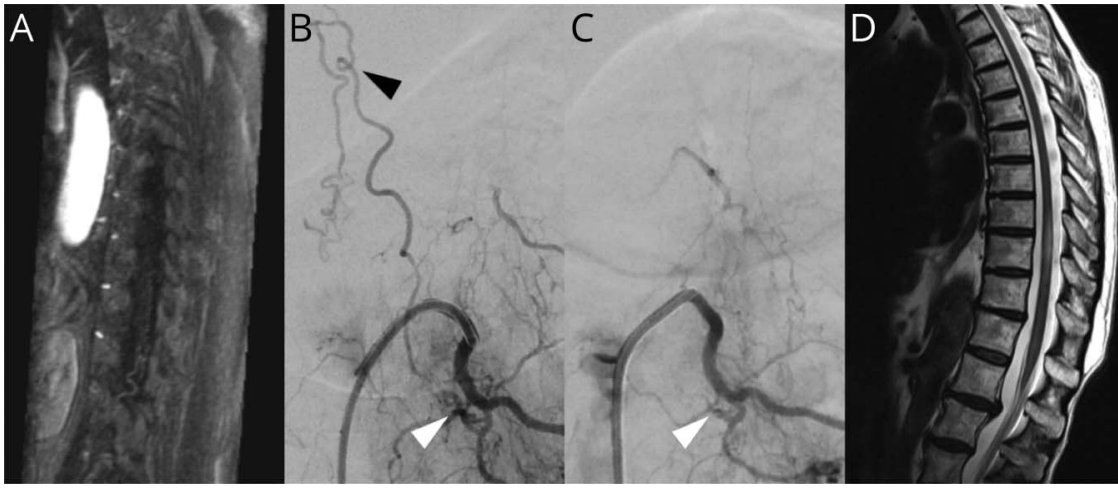

(A) Magnetic resonance angiography reveals dorsal subarachnoid vascular conglomerate. (B) Selective angiogram shows spinal dural arteriovenous fistula at left L1 level (white arrowhead) and engorged ascending perimedullary vein (black arrowhead). (C, arrowhead) Endovascular embolization was successful. (D) Note decreased spontaneous spinal T2 hyperintensity.

Appendix Authors

\begin{tabular}{|c|c|c|}
\hline Name & Location & Contribution \\
\hline $\begin{array}{l}\text { Andre } \\
\text { Miguel } \\
\text { Miranda, } \\
\text { MD, PhD }\end{array}$ & $\begin{array}{l}\text { Department of Imagiology, } \\
\text { Neuroradiology Unit, Centro } \\
\text { Hospitalar de Vila Nova de } \\
\text { Gaia/Espinho EPE, Vila Nova } \\
\text { de Gaia, Portugal }\end{array}$ & $\begin{array}{l}\text { Drafting/revision of the } \\
\text { manuscript for content, } \\
\text { including medical writing for } \\
\text { content; major role in the } \\
\text { acquisition of data; analysis } \\
\text { or interpretation of data }\end{array}$ \\
\hline $\begin{array}{l}\text { Marta } \\
\text { Gomes } \\
\text { Rodrigues, } \\
\text { MD }\end{array}$ & $\begin{array}{l}\text { Department of Imagiology, } \\
\text { Neuroradiology Unit, Centro } \\
\text { Hospitalar de Vila Nova de } \\
\text { Gaia/Espinho EPE, Vila Nova } \\
\text { de Gaia, Portugal }\end{array}$ & $\begin{array}{l}\text { Drafting/revision of the } \\
\text { manuscript for content, } \\
\text { including medical writing for } \\
\text { content; analysis or } \\
\text { interpretation of data }\end{array}$ \\
\hline $\begin{array}{l}\text { Andre } \\
\text { Araujo, MD }\end{array}$ & $\begin{array}{l}\text { Department of Imagiology, } \\
\text { Neuroradiology Unit, Centro } \\
\text { Hospitalar de Vila Nova de } \\
\text { Gaia/Espinho EPE, Vila Nova } \\
\text { de Gaia, Portugal }\end{array}$ & $\begin{array}{l}\text { Drafting/revision of the } \\
\text { manuscript for content, } \\
\text { including medical writing for } \\
\text { content }\end{array}$ \\
\hline $\begin{array}{l}\text { Manuel } \\
\text { Queiros } \\
\text { Ribeiro, MD }\end{array}$ & $\begin{array}{l}\text { Department of Imagiology, } \\
\text { Neuroradiology Unit, Centro } \\
\text { Hospitalar de Vila Nova de } \\
\text { Gaia/Espinho EPE, Vila Nova } \\
\text { de Gaia, Portugal }\end{array}$ & $\begin{array}{l}\text { Drafting/revision of the } \\
\text { manuscript for content, } \\
\text { including medical writing for } \\
\text { content; major role in the } \\
\text { acquisition of data; analysis } \\
\text { or interpretation of data }\end{array}$ \\
\hline
\end{tabular}

Appendix (continued)

\begin{tabular}{|c|c|c|}
\hline Name & Location & Contribution \\
\hline $\begin{array}{l}\text { Henrique } \\
\text { Costa, MD }\end{array}$ & $\begin{array}{l}\text { Department of Neurology } \\
\text { (H.C.), Centro Hospitalar de } \\
\text { Vila Nova de Gaia/Espinho } \\
\text { EPE, Vila Nova de Gaia, } \\
\text { Portugal }\end{array}$ & $\begin{array}{l}\text { Drafting/revision of the } \\
\text { manuscript for content, } \\
\text { including medical writing } \\
\text { for content; major role in } \\
\text { the acquisition of data; } \\
\text { analysis or interpretation of } \\
\text { data }\end{array}$ \\
\hline $\begin{array}{l}\text { Sergio } \\
\text { Castro, MD }\end{array}$ & $\begin{array}{l}\text { Department of Imagiology, } \\
\text { Neuroradiology Unit, Centro } \\
\text { Hospitalar de Vila Nova de } \\
\text { Gaia/Espinho EPE, Vila Nova } \\
\text { de Gaia, Portugal }\end{array}$ & $\begin{array}{l}\text { Drafting/revision of the } \\
\text { manuscript for content, } \\
\text { including medical writing } \\
\text { for content; major role in } \\
\text { the acquisition of data; } \\
\text { analysis or interpretation of } \\
\text { data }\end{array}$ \\
\hline
\end{tabular}

\section{References}

1. Kannath SK, Mandapalu S, Thomas B, et al. Comparative analysis of volumetric highresolution heavily T2-weighted MRI and time-resolved contrast-enhanced MRA in the evaluation of spinal vascular malformations. Am J Neuroradiol. 2019;40(9): 1601-1606.

2. Zalewski NL, Rabinstein AA, Brinjikji W, et al. Unique gadolinium enhancement pattern in spinal dural arteriovenous fistulas. JAMA Neurol. 2018;75(12):1542-1545. 


\section{Neurology}

\section{Teaching NeuroImages: MRI Abnormalities of Spinal Dural Arteriovenous Fistula in the Absence of Flow Voids}

Andre Miguel Miranda, Marta Gomes Rodrigues, Andre Araujo, et al. Neurology 2021;97;e324-e325 Published Online before print April 26, 2021

DOI 10.1212/WNL.0000000000012053

\section{This information is current as of April 26, 2021}

\section{Updated Information \&} Services

References

Subspecialty Collections

Permissions \& Licensing

Reprints including high resolution figures, can be found at: http://n.neurology.org/content/97/3/e324.full

This article cites 2 articles, 1 of which you can access for free at: http://n.neurology.org/content/97/3/e324.full\#ref-list-1

This article, along with others on similar topics, appears in the following collection(s):

\section{All Pain}

http://n.neurology.org/cgi/collection/all_pain

All Spinal Cord

http://n.neurology.org/cgi/collection/all_spinal_cord

Clinical neurology examination

http://n.neurology.org/cgi/collection/clinical_neurology_examination MRI

http://n.neurology.org/cgi/collection/mri

Information about reproducing this article in parts (figures,tables) or in its entirety can be found online at:

http://www.neurology.org/about/about_the_journal\#permissions

Information about ordering reprints can be found online:

http://n.neurology.org/subscribers/advertise

Neurology ${ }^{\circledR}$ is the official journal of the American Academy of Neurology. Published continuously since 1951 , it is now a weekly with 48 issues per year. Copyright @ 2021 American Academy of Neurology. All rights reserved. Print ISSN: 0028-3878. Online ISSN: 1526-632X.

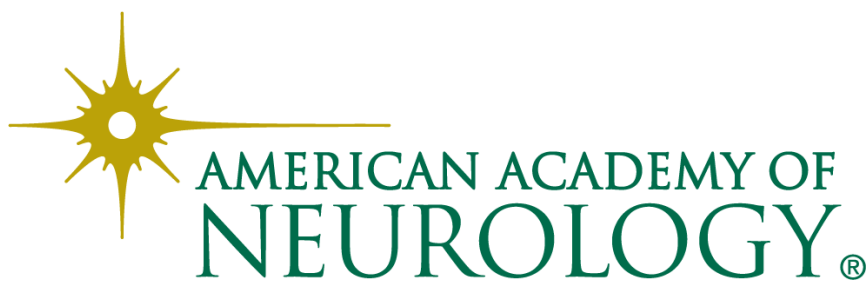

